University of Colombo Review (Series III),

Vol. 1, No. 1, 2020

\title{
Global Narratives, Local Realities: Probing Issues of Justice through Theatre Translation as Renarration
}

\section{Dinithi Karunanayake}

Senior Lecturer, Department of English, University of Colombo

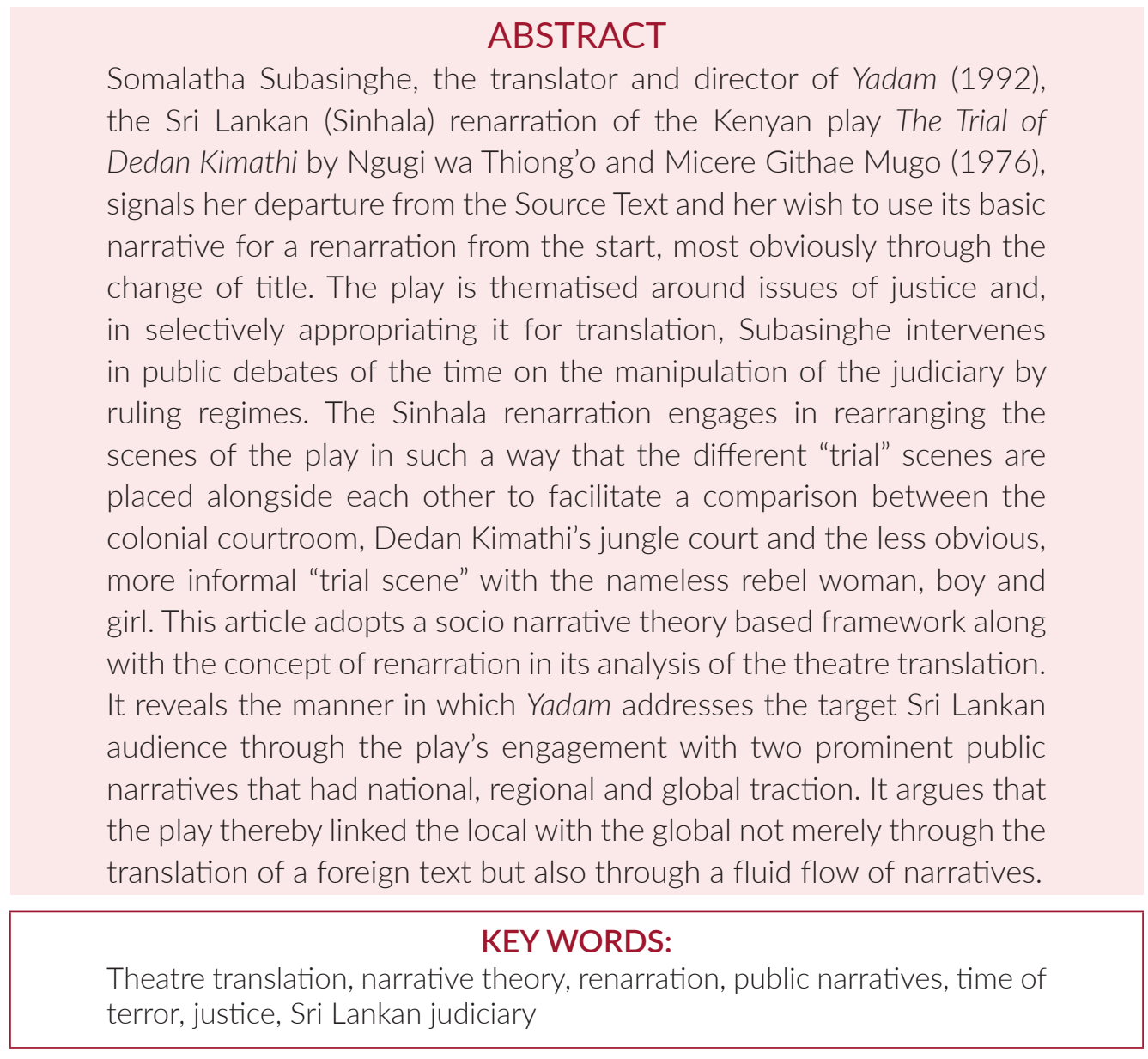

Suggested Citation: Karunanayake, D. (2020). Global Narratives, Local Realities: Probing Issues of Justice through Theatre Translation as Renarration. University of Colombo Review (Series III), 1 (1), 119 - 138

(C) 2020 The Authors. This work is licenced under a Creative Commons Attribution 4.0 International Licence which permits unrestricted use, distribution, and reproduction in any medium, provided the original work is properly cited. 


\section{Introduction}

The legal system is one of the most important institutions in a modern democracy and becomes, arguably, one of the most potent tools of control that a government possesses. It is through the legal system and the enactment of laws that societies are regulated. Whilst in an ideal state the legal system should protect the citizens of a country, this does not always happen in practice. Rather, one might even say that the legal system protects the government and its interests so as to make governance possible. As Udagama notes, "[o]ften, governments subvert the legal system in order to unleash violence on the populace and terrorize them" (1998, p. 75). Such subversions are particularly evident in times of conflict, when a government attempts to ensure its own wellbeing through the enactment of Emergency Regulations and various forms of censorship. This was the case in Sri Lanka during the 1971 - 2009 period, a period of intense political turmoil that witnessed the country going through two youth insurrections and four Eelam wars. ${ }^{1}$

This article examines the ways in which a theatre translation, Yadam $^{2}$ (Subasinghe, 1992), attempts to intervene in debates concerning the judiciary and issues of justice in the aftermath of the 1988-89 JVP (Janatha Vimukthi Peramuna) insurrection and Eelam wars I-II in Sri Lanka. Yet, as the term itself makes evident, theatre translation involves, at times, the use of a (foreign) Source Text (ST) to address a (local) target audience. Meaning making is therefore complicated by the existence of a ST that obviously addresses a different audience. The question then is, how might this text, subsequently and in translation, address an alternate socio-cultural political target context? What are the translation processes that theatre texts undergo to address this differently constituted audience? In order to explore these questions further, a socio narrative theory based framework and the concept of translation as renarration are adopted to understand the nature of such global-local interactions which occur not only through the adoption of a foreign text for translation, but also and more significantly through the public and meta narratives that both influence the renarration and are, in turn, nourished by it.

In employing narrative theory in the analysis of theatre translation, it is important at the outset to acknowledge that theatre primarily involves a meaning making process and a communicative act and that there is an audience that is imagined for each theatrical production. It could be argued that all dramatic performances also involve the elaboration of narratives, whether in the form of a story that unfolds on stage via scripted dialogue or by means of a performance. Theatricality, which forms a different kind of language, communicates through dance, movement, scene setting and costume, or taking audience members through experiences and into sites and spaces. As David Johnston points out,

[t]he theatre translator needs to eke out language in its performative context, to write forward, to bring the potentials for performance that are encoded in the original explicitly into the temporal and spatial purview of the audience - in short, to engage on behalf of the new receiving context with the sweep and scope of the text's possible meanings. (2013, p. 366)

In performance, the script and the theatrical work in concert to create meaning. These meaning making processes are shared and the narratives that emerge are co-constructed with the active involvement of the audience as well as that of the theatre practitioners. 
The sociological manifestation of narrative theory-or socio-narrative theoryemployed as an analytical vector in this article is based on Somers (1994), Somers and Gibson (1994) and Baker (2006). This version of narrative theory is significantly different to narratological/linguistic approaches that view narrative as a representational and optional form of communication (Baker, 2006, p. 9). Narrative in this understanding does not reflect, but rather constitutes reality: social life itself is "storied" and narrative is hence "an ontological condition of social life" (Somers \& Gibson, 1994, p. 38). As Somers and Gibson point out, what is important about this model is that it provides a "narrativist understanding of social action and social agency" that is "temporal, relational and cultural as well as macro-structural" (1994, p.41). Thus, "this is a theoretical perspective that attends to the particularities of human lives whilst also locating those lives within a social world" (Karunanayake, 2017, p. 152). Socio-narrative theory, founded on the idea that narrative mediates our engagement with multiple realities, provides an important analytical lens because recognition that narratives are assembled and that multiple realities exist, presents us with the possibility for "creating alternative narratives to those legitimised by governments and other powerful actors" (Karunanayake, 2017, p. 152). It alerts us to the fact that we make sense of our worlds through narrative and contribute to their narration. In fact, it is such a perception of the role of narrative that legitimises the analysis of theatre translation as a political and activist intervention in narrative(s) of conflict.

\section{Theatre Translation as Renarration?}

Viewing theatre translation through narrative theory and the notion of renarration ${ }^{3}$ provides fresh insights into issues surrounding the translation of plays and their engagement with target contexts for several reasons. Firstly, the idea of renarration implies a retelling. The emphasis of the retelling can be different from that of the ST and hence the need for semantic accuracy would be far less relevant in this kind of interpretation of the translation process. Such an interpretation also aligns itself with current theorising of translation as exemplified by Theo Hermans $(2007,2010)$ who makes a distinction between translations, and texts that cannot be considered as translations: "a translation cannot be equivalent to its original" because "[a] translation that is equivalent to its original, that is recognized as equivalent and functions as such, ceases to be a translation and becomes a version on par with the original, one version among other versions of the same work" (Hermans, 2010, p. 64; emphasis in original).

This means we can take it as a given that the translated drama text under discussion will be different from the ST because it is presented as a translation and not as a different version of the ST. One of the clearest and perhaps most superficial indications of this, if we need one, is the fact that some theatre translations are produced under an entirely different title to that of the ST. For instance, similar to Somalatha Subasinghe's Sinhala translation of Ngugi Wa Thiong'o's and Micere Githae Mugo's The Trial of Dedan Kimathi being titled Yadam [Chains], Dharmasiri Bandaranayake's Sinhala production of Jean Paul Sartre's Men Without Shadows is titled Dhawala Bheeshana [White Terror] and Vijitha Guneratne's Sinhala translation of Dario Fo's Accidental Death of an Anarchist is called 
Sakki [Evidence]. The Sinhala language has the vocabulary and resources to render a close translation of the title in each case, or at least one that more obviously relates the translation

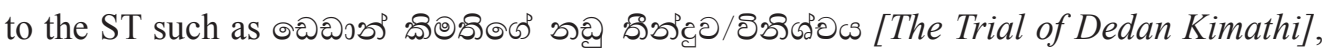

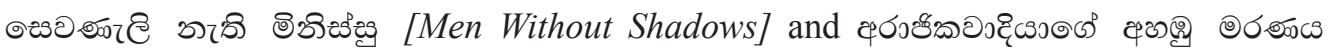
[Accidental Death of an Anarchist]. The instances in which title changes are made stand out, therefore, due to the fact that, more often than not, theatre translations retain a close connection to their ST titles. ${ }^{4}$ This is especially so when a ST contains a personal name. ${ }^{5}$

A narrativist understanding of translation makes us aware that such choices are never merely due to a perceived (in)ability to produce an equivalent title for the Target Text (TT) in the target language. The narrative significance of such choices can be theorised through the concept of selective appropriation (as will be demonstrated in the analyses of Yadam later on in the article). It can therefore be argued that changes to the titles, which convey particular nuances of context, are indicative of a desire for a renarration from the perspective of the target culture and context.

The idea of translation as renarration appears to be more "performance sensitive" because, unlike the concepts of translation as "rewriting" (Lefevere, 1992) or as "quotation" (Hermans, 2007, 2010) which foreground the textual dimension, narrative theory acknowledges the use of diverse elements in the narrative process. Thus a renarration can make use of textual, verbal and nonverbal elements such as costumes and lighting, movement, dance, music and silence in performance in addition to the script itself, as well as promotional material such as posters and advertisements, pre-release interviews, post-performance reviews, and opinion pieces. This kind of translation method, which deemphasises the authority of the text and minimises the dependence of performance on it, resonates with current thinking in performance studies. For instance, Jürs-Munby notes that due to the "new emphasis on performance in European and North American theatre and art from the 1960s onwards [...] the text [became] just one element in the scenography and general 'performance writing' of theatre" (2006, p. 4). Similarly, in his prologue to Postdramatic Theatre, Lehmann articulates the focus of his text in the following manner: "the discourse of theatre is at the centre of this book and the text therefore is considered only as one element, one layer, or as a 'material' of the scenic creation, not as its master" (1999/2006, p. 17; emphasis in original). Thus, adopting the concept of renarration as a framework to investigate theatre translation is in keeping with trends in performance studies. Significantly, in the context of this article, the text as "one element, one layer" or "material" for scenic production also resonates with the use by Sri Lankan dramatists of intermediary translations ${ }^{6}$ in their work. Whilst this downgrading of the textual element is sometimes seen as problematic within translation studies, we need to remember that these translations are produced for performance purposes and in that context the drama text, as the preceding discussion notes, is only one element of the theatrical process.

The very definition of a re-narration, (or a rewriting or quoting) implies a preceding narration (writing or text). Thus, it would seem that renarration, whether in the same language or in a different language, is constrained by an already existing narrative. In the case of translation, there is further constraint in that the source narrative usually 
exists in a stable form - whether written, oral, or visual - and the translation is subject to comparison with the earlier narrative for equivalence. Whilst we could state that all human communication is in a sense renarration, that no utterance or text is "original" (particularly given the understanding we have derived through narrative theory), and that we can only draw on a repertoire of already existing stories in configuring any kind of narrative, the strength of the concept of renarration lies in the fact that it moves us away from the idea of repeating, particularly textual material. ${ }^{7}$ A retelling of a narrative also implies the active participation of a narrator ${ }^{8}$ and is, therefore, akin to the oral tradition of storytelling where no telling is the same as the one before. There is also an element of performativity in storytelling, and a sense in which the temporal moment of telling and its spatial context become unique and significant. Storytelling is anchored in time and space. As Johnston states, "translation for the stage is about giving form to a potential for performance" (1996, p. 58). To view theatre translation as renarration within such an understanding seems particularly productive, especially within the context of local-global connectivities through both narrative and translated theatre.

\section{The Source Text and Context}

In order to fully appreciate the renarration embedded in the theatre translation under discussion, an understanding of the ST and context is useful. The Trial of Dedan Kimathi (TDK), the ST for Yadam, written collaboratively by Ngugi wa Thiong'o' and Micere Githae Mugo, is their response to colonialist representations of the Mau Mau movement and one of its leaders, Dedan Kimathi, as cruel and psychologically unsound (1977, p. iv). In their play, wa Thiong'o and Mugo counter this image with a portrait of Kimathi as a man of great courage and commitment. As they say in their introductory comments to the play, they "[envision] the world of the Mau Mau and Kimathi in terms of the peasants' and workers' struggle before and after constitutional independence" (1977, p. iv). Dedan Kimathi was captured and put on trial in 1956 and the play focuses on this historic narrative.

The three acts in this play are referred to as "movements"; according to the "preliminary note" presented at the beginning of the published script, the three movements "should be viewed as a single movement" so that the "action [is] on the whole [...] seen as breaking the barrier between formal and infinite time, so that past and future and present flow into one another" (wa Thiong'o \& Mugo, 1977, p. 2). The action takes place in several different locations: a colonial courtroom, Dedan Kimathi's prison cell, a street in Nairobi, a street in Nyeri and a Mau Mau camp in the forest.

The play begins with Dedan Kimathi's trial, ostensibly for possession of a firearm. In the first movement, Waitina, a white police officer, and his soldiers intimidate the natives, searching for them, demanding their passbooks, and arresting innocent villagers on suspicion that they support the Mau Mau. In a conversation between two soldiers it is revealed that they hope the struggle for independence will end with Kimathi's execution. The audience is introduced to the nameless woman, boy and girl who later play a significant role in the action. The girl and boy are seen to be fighting over money; the unnamed woman intervenes and resolves the conflict. The boy is given a loaf of bread that the woman carried 
in her bag and protected from the soldiers in an earlier encounter with them. The woman tells the boy that he must bring the loaf of bread and come to the courtroom to attend Dedan Kimathi's trial. The first movement ends with the boy resolving to be at the trial and abide by the words of the woman.

The second movement begins with a description of the scene outside the courtroom; the unnamed women is seen in disguise as a male fruit seller and she appears to be looking out for someone. The scene shifts to the courtroom and both white settlers and natives enter the court. Dedan Kimathi is brought before Shaw Henderson, the white judge. Kimathi questions the legitimacy of the court set up by the colonialists to administer their own laws. An armed white settler abuses the Kenyans in the courtroom after the Judge adjourns the trial. First the boy and then the girl enter the stage, they see each other and the boy chases after the girl; they leave the stage, with the loaf of bread, having missed the woman in male disguise.

1st trial: Shaw Henderson visits Kimathi's cell, described as resembling a court. Henderson represents the coloniser and attempts to convince Kimathi to plead guilty. Kimathi is told that his life will be spared in exchange for his assistance in rooting out the Mau Mau. Kimathi turns him down. 2nd trial: Bankers who promise prosperity for Kenya if Kimathi ends the armed struggle visit the prison cell. They too are turned away by a defiant and idealistic Kimathi. 3rd trial: A black business executive, a politician, and a priest attempt to convince Kimathi to give up the struggle for the sake of his fellow Kenyans so that their country may prosper. Kimathi dismisses them. 4th trial: When these appeals fail, Henderson returns, strikes Kimathi and orders him to be whipped.

The third movement begins with the boy and the girl, now working together. They meet and recognise the woman still dressed as a male fruit seller. The woman commends the girl and boy for putting their differences aside and working together for a common and worthy cause. The boy and girl pledge to support the woman in her attempt to free Dedan Kimathi, viewed with awe by them both.

In flashback, we see Kimathi in his camp in the jungle. A Mau Mau court of law is presented with Dedan Kimathi presiding as judge. Two different sets of "offenders" are brought before him: the first set includes two British soldiers and one African soldier, all part of the colonial army; the second set of offenders are Mau Mau rebels who have "betrayed the cause", including Kimathi's own brother. This scene ends with the escape of the collaborators and the implication that it was their betrayal that led to the final arrest of Kimathi. It brings the action back to the play's present moment.

The final scene takes place once more in the colonial courtroom and the context of Kimathi's trial. Kimathi is sentenced to death, but the girl and the boy whose narrative has been presented throughout the play, produce a gun from the loaf of bread they have been protecting and free Kimathi. The girl and boy lead a final triumphant chorus.

In the play, "there is impersonation, merging of characters and reflection of history emphasising the complexity, duality and interrelationships of people and events" (wa Thiong'o \& Mugo, 1977, p. 2). Accordingly, the audience is presented with song, mime and dance performances that narrate Kenya's past and link it to the play's present action. 
These are presented at strategic moments in the play and are important to the narrative task of rewriting history to which TDK contributes (Brown, 1999; Dione, 2018; Magel, 1983).

\section{The Translation Context}

Translation enables complex interactions between texts and contexts. Texts such as $T D K$ travel across temporalities and geographies through translation. They interact with the target contexts through renarration, both drawing on and contributing to narrative landscapes (as will be further explained in the following sections). These renarrations, in turn, inspire fresh interpretations and readings of STs that ensure, in Benjamin's words, "their stage of continued life" (1996, p. 254).

Yadam was first performed in Sri Lanka in 1992 by which time two insurgencies by the JVP had already taken place: the first in 1971 and the second from 1988-1989, referred to in Sri Lanka as the Bheeshana Kaalaya (time of terror) or simply Bheeshanaya (terror) because the country was also going through the second Eelam war by 1990. It could be argued that Yadam (produced and performed in the immediate aftermath of the second JVP rebellion and in the midst of the second Eelam war), addressed a country that had seen violence both from the government and factions supposedly offering political alternatives to mainstream politics. Both the JVP and the LTTE (Liberation Tigers of Tamil Eelam) had, by 1992 , embarked on militancy and guerrilla warfare in order to achieve their political goals. Thus, the context addressed by the theatre translation was quite different to the postindependence Kenyan context which its ST addressed.

As is perhaps the case with all conflict contexts, the 1990s in Sri Lanka was a time in which extreme measures of surveillance and censorship operated. Censorship: A World Encyclopaedia, noted that in Sri Lanka, censorship "imposed both by governments and armed opposition groups [...] affected the press, broadcasting, artistic expression, political activity, and the public at large" (Nissan, 2001, p. 2330). The encyclopaedia entry goes on to state that the imposition of censorship took varied forms in Sri Lanka, ranging from formal regulatory structures governing the arts, film, the press and broadcasting to violent intimidation and death squad assassinations (2001: 2330). However, Ranjini Obeyesekere in Theatre in a Time of Terror (1999) observes that theatre was a medium that managed to navigate power and censorship. It raised social consciousness on issues of justice and fair play throughout the late 1980s and the 1990s (the period of her study) during which the theatre translation under discussion was produced and performed.

\section{The Sinhala Renarration: Somalatha Subasinghe's Yadam}

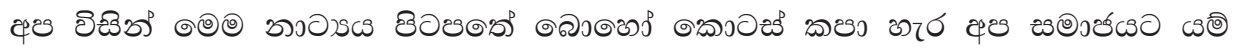

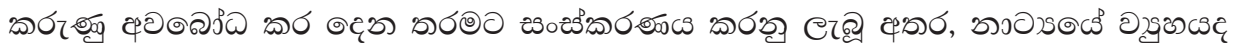

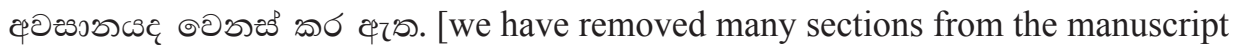
and edited it so as to impart certain facts on our society. The structure of the play and the ending have been changed] (Subasinghe, 1992, n.p.; my translation). 
Although audiences would not have access to this statement, it very clearly articulates the translator/director's aim vis-à-vis her theatre translation. Despite this clearly articulated desire to address a 1990s Sri Lankan audience through Yadam, the performance retained place names and names of people from $T D K$; the majority of costumes reflected a Kenyan or African context as did the music, dance and references to food. These decisions can be understood in the context of the climate of censorship that existed in Sri Lankan in 1992. Yet, the narrative feature of temporality alerts us to the fact that the significance of any narrative occurrence can only be understood in relation to a specific context. The manner in which narratives are positioned/sequenced in time and/or space is referred to as temporality in narrative theory (Baker, 2006; Somers \& Gibson, 1994). ${ }^{9}$ How then would an audience connect the narrative presented in the translation to their own context? An examination of the publicity material used for the production reveals that in all the material, the title Yadam is preceded by the phrase ' [my translation: the symbol of third world oppression]. Thus, a connection is established between Postcolonial Kenya, the source milieu, and 1990s Sri Lanka, the target setting, as "Third World" contexts. A further strategy used by Subasinghe is in an alteration to the opening scene of her theatre translation: instead of opening the play with a courtroom scene featuring Dedan Kimathi as the source text does, the Sinhala renarration opens with a protest march.

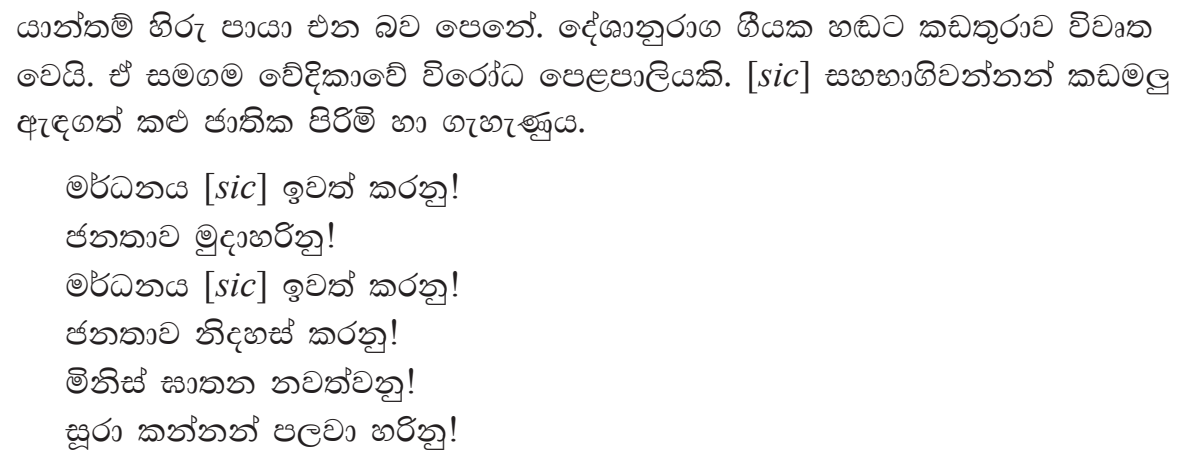

[my back translation:

The sun is seen to be just rising. The curtain opens to a nationalist song. At the same time, there is a protest march on stage. The protesters are black men and women, dressed in rags.

Down with oppression!

Release the people!

Down with oppression!

Free the people!

Away with human slaughter!

Away with exploiters!] (Subasinghe, 1992, p. 1)

Although $T D K$ has a similar protest march, it is not the opening sequence of the play as in the case of Yadam. Much more importantly though, a ST and TT comparison reveals that the slogans used in the Sinhala renarration are slightly different to those used in the ST: 
Leader: Away with oppression!

Unchain the people!

Crowd: Away with oppression!

Unchain the people!

Song: [...]

Leader: Away with exploitation!

Unchain the people!

Crowd: Away with oppression!

Unchain the people!

Leader: Away with human slaughter!

Crowd: Unchain the people!

Leader: Brothers we shall break-

Crowd: Exploiters' chains!

Leader: Rally round the gun!

Crowd: Make a new earth! (wa Thiong'o \& Mugo, 1977, p. 5)

Clearly then, the protest march, a highly familiar phenomenon in the 1990s Sri Lankan setting, and the slogans are selectively appropriated to create a connection between a seemingly foreign context and the local milieu.

The source narrative places Dedan Kimathi at its centre. This becomes evident not only through the title of the play but also its opening scene: a court room in which the white judge reads out the charges against Kimathi. Audience attention is directed towards the silent and defiant Kimathi through a spotlight, as he stands in the dock, refusing to answer the European judge's repeated query "guilty or not guilty?" The Sinhala renarration however commences with a scene from the streets: a protest rally that is subsequently attacked by the soldiers of the colonial forces. This change, or selective appropriation of a scene in narrativist terms, indicates a shift in focus from a single heroic figure, admired and loved by the people, to the people themselves, presented as courageous and resilient.

In Yadam, a link is created between the colonial judiciary in Kenya and the legal system in Sri Lanka through the costume adopted for Kimathi which resembles the clothes worn by 20 th century Sri Lankan prisoners, whilst all the other characters wear costumes that are either reflective of Kenyan attire or those worn by British colonials in the 1950s and 1960s. In theatrical terms, the juxtaposition works to focus audience attention on Kimathi's attire. Through the narrative devises of selective appropriation and temporality via her use of costume, Subasinghe mobilises a powerful critique of the judiciary in contemporary Sri Lanka as Kimathi's trial is depicted as a sham, a travesty of justice and the law, as will be explained in the paragraphs below. Significantly, the human mind can only make sense of events and narrative elements if they are presented as part of a story. It is otherwise impossible for our minds to make sense of independent or isolated events (Bruner, 1991). Thus, relationality ${ }^{10}$ is vital in sense making: it concerns how events and other elements relate to one another within the context of a whole narrative. Through this narrative feature, connections between the various narrative elements including the use of titles, specific scenes, costumes and much more are established to create a coherent narrative. 
Thus, a relational connection is established between the colonial judiciary depicted in TDK and the Sri Lankan one in Yadam based on the colonial origins of the Sri Lankan justice system. ${ }^{11}$

Having related the theatre translation to the local context in these ways, Subasinghe proceeds to engage in a renarration of $T D K$ through her translational and directorial choices, and selective appropriation. The narrative feature of selective appropriation involves the selection of certain elements over others. As Somers and Gibson note, "in the face of a potentially limitless array of social experiences deriving from social contact with events, institutions, and people the evaluative capacity of emplotment demands and enables selective appropriation in constructing narratives" (Somers \& Gibson, 1994, p. 60; emphasis in original). Plots are thematic (Polkinghorne, 1995; Somers \& Gibson, 1994). The way events are processed and the criteria used for prioritising and providing meaning to events depend on the narrative theme (Somers \& Gibson, 1994). As White points out, "every narrative, however seemingly 'full', is constructed on the basis of a set of events that might have been included but were left out" (1987, p. 10). In the case of theatre translation, an examination of what was left out would be as significant and interesting as what is included and emphasised through selection. Thus, for instance, the change of title enables Subasinghe to connect her renarration with the target culture and context with greater ease than had she retained a name-Dedan Kimathi-that is unfamiliar to Sri Lankan audiences. Yadam or "Chains" also resonates with prisoners/prisons, trials and the judiciary by extension - all significant issues in the context of Sri Lanka in the post JVP and Eelam war period. ${ }^{12}$

Summary arrests, disappearances and death squads were among the atrocities the Sri Lankan public endured during this time (Coomaraswamy \& de los Reyes, 2004; Lynch, 2019; Udagama, 1998;). Thus, the justice system which was under scrutiny in Sri Lanka during the 1990s becomes the focus of the Sinhala renarration. Udagama noted that,

[t]he recent process of democratization all over the globe has focussed attention on the role of the judiciary in consolidating democratic rule and safeguarding social justice. States in the South have paid particular attention to the role of the judiciary in establishing social justice (1998, p. 270).

Thus, scrutiny of the judiciary in the 1990s, whether on the part of the state or civil society (as was the case in Sri Lanka) (Udagama, 1998) constituted a particular "public narrative", described as "shared stories that are elaborated by and circulate among a group as small as a family or potentially as large as the whole world" (Baker, 2014, p. 161). They "provide models for behaviour (social roles) and for acting within particular spaces, without which individuals would be unable to conceive of how to position themselves in relation to the social world" (Baker, 2006, p. 29). The potency and vigour of a public narrative depends on the number and power of its adherents. Given that narrative engagements with the role of the judiciary had wide global subscription in the 1990s as Udagama (1998) points out (and Sri Lanka's penal reforms of 1995 provide an example), it is perhaps not surprising that Subasinghe deals with this set of public narratives in Yadam. This also points to how the local connects with the global through narrativity. 
Just as electing to translate and perform particular scenes and not others through a process of selective appropriation is important to the task of renarration, the rearrangement of scenes is also meaningful. This points to how the narrative feature of causal emplotment, "an accounting (however fantastic or implicit) of why a narrative has the story line that it does" (Somers \& Gibson 1994, p. 59) has been employed in the renarration. This feature is sometimes considered the most important feature of narrativity for two main reasons. Firstly, "[t]he configurative process employs a thematic thread to lay out happenings as parts of an unfolding movement that culminates in an outcome. The thematic thread is called the plot, and the plot's integrating operation is called emplotment" (Polkinghorne, 1995, p.5). Thus the feature of emplotment is central to the narrative process in structural terms. Secondly, this is the feature that can be associated with the impulse to moralise, which, according to Hayden White (1987), is at the heart of narrativity, distinguishing it from other forms of (historical) documentation. The Sinhala renarration engages in rearranging the scenes of the play in such a way that the different trial scenes are placed alongside each other to facilitate a comparison between the colonial courtroom, Dedan Kimathi's jungle court and the less obvious, more informal trial scene with the nameless rebel woman, boy and girl who are in fact the first key figures presented in Yadam. Thus, instead of presenting Kimathi's jungle court in the third movement as $T D K$ does, the Sinhala renarration presents it immediately after the first trial, in the second movement, clearly encouraging a comparison between the colonial and rebel courts.

Significantly, the manner in which justice is meted out in both the colonial court and the jungle court of Dedan Kimathi are remarkably similar. They are both predominantly masculine spaces characterised by their unforgiving and harsh judgements. Just as Kimathi receives no sympathy from, or a fair hearing in the colonial court, the two British soldiers and the African soldier who are part of the colonial army receive no sympathy from him and are executed after a perfunctory hearing. The Mau Mau men accused of treachery in Kimathi's court, including Kimathi's own brother, are treated more compassionately as they are seen as fellow freedom fighters. Although this is presented as a sign of Kimathi's humanness in $T D K$, one may also argue that it points to a double standard quite similar to that of the coloniser. The kind of partisanism exhibited in each case engages with the public narrative on the role of the judiciary. In theatricalising the court room in Yadam, the idea that justice is performed is broached. The privileged position afforded to courts of law as spaces that ensure impartial and unassailable forms of justice is thus undermined through the staging of justice in Yadam which implies that justice is also staged.

Of the three courts that are presented through the renarration, it is the informal court with the nameless woman as Judge that manages to resolve a problem between the two parties, enabling them to subsequently work together. Whilst a number of scenes with Kimathi, including the opening scene that presents the colonial court room and a stoically heroic Kimathi are removed from the Sinhala renarration, a significant amount of narrative and stage time are devoted to the nameless woman and her "trial scene" on the street with the nameless boy. The theatre translation explores the modalities operant in this trial as opposed to the others, revealing a questioning of legal processes and how they are 
imbricated in state and economic structures. Trials 1-3 in the second movement of TDK that are retained with minimal change in the TT are especially pertinent to this narrative thread. The influence that colonial administrators, bankers, local and international business people and finally the priest try to exert over Kimathi and a court case speak of interference with legal processes or the due process of law. Furthermore, although there appears to be a "hearing", Kimathi's responses are not "heard" in the colonial court. The judge has clearly already reached his verdict and the trial is an attempt to coerce Dedan Kimathi to go along with the narrative or, in theatrical terms, the script that the colonial authorities have decided on. In contrast to this, the nameless rebel woman in her role as Judge is both empathetic and perceptive in her engagement with her "defendant", the nameless boy. Unlike in the other trial scenes, she gives a fair hearing to the boy's narrative and creatively reorients his priorities so as to ensure that no antagonism can arise between him and the nameless girl, his former antagonist.

Just as much as narrative meaning is created through the order in which episodes are presented, the amount of stage time allotted to each narrative episode carries meaning, as it is indicative of the significance awarded to them. Thus, Subasinghe continues her privileging of the people's narrative by giving them, and Kimathi, equal space within the renarration. Particularly evident in this light is the place and prominence given to the unnamed woman, boy and girl. An analysis of two seminal scenes in the renarration provides us with an insight into how their narrative contributes to yet another conflict related public narrative.

\section{Local-Global Connectivity through Narrative}

The JVP and the LTTE were known to have had children's wings (Fonseka, 2001; Gunaratne, 1995; Singer, 2004; Wikramaratne, 2019). The conscription of school children by these organisations was under scrutiny from the late $1980 \mathrm{~s}$; it seems pertinent to the discussion that the $A-Z$ of Conflict, a tri-lingual (English, Sinhala and Tamil) artists' book containing an archive of words and images engaging with diverse perceptions / articulations

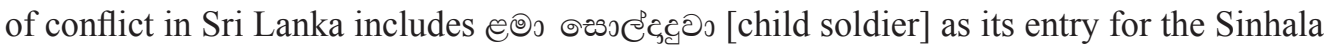
letter $\in$ (Azeez, 2019). Given that the context referred to in this book is Sri Lanka and its conflicts, the entry, it can be argued, is indicative of the importance of the "children in conflict" public narrative. The fact that Yadam participates in and contributes to this particular narrative is clear in the following lines (also found in $T D K$ ):

Woman: $[\ldots]$ But listen, there is an urgent task to be done. Kimathi is appearing in court to-day. This afternoon. Would you like to run a mission for Kimathi?

Boy: My life; what would I not give?

Woman: Talking is easy. It is deeds that show a man.

Boy: I am ready. (wa Thiong'o \& Mugo, 1977, p. 20)

Yadam presents these lines in the following manner:

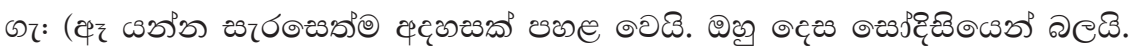

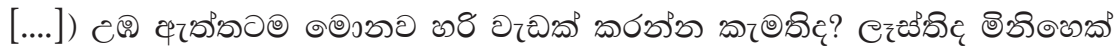

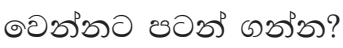

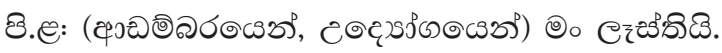




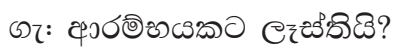

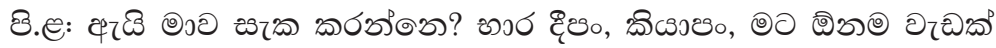

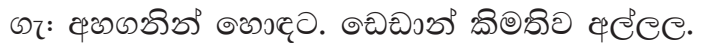

ช.ల: ขి๑3త ฉిఁ3วอ.

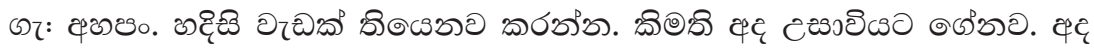

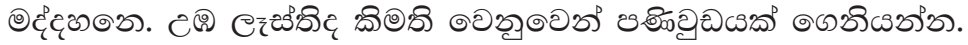

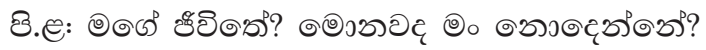

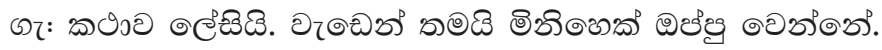

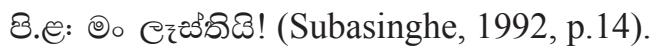

[my back translation:

Woman: (As she's about to leave she gets an idea. She looks inquiringly at him [...] are you really ready to do some work? Ready to start becoming a man?

Boy: (with pride and enthusiasm) I'm ready.

Woman: Ready for a [new] beginning?

Boy: Why do you doubt me? Give me a task, tell me, any job!

Woman: Listen carefully. Dedan Kimathi has been captured.

Boy: So they say.

Woman: Listen. There's an urgent task (to be done). Kimathi will be brought to court today. At noon. Are you prepared to take a message for Kimathi?

Boy: My life? What wouldn't I give?

Woman: Talk is easy. Actions prove you're a man.

Boy: I'm ready! ]

Reading these lines alongside the definition by the artist Abdul Halik Azeez for his entry "child soldier" in the $A-Z$ of Conflict proves to be quite revealing:

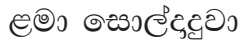

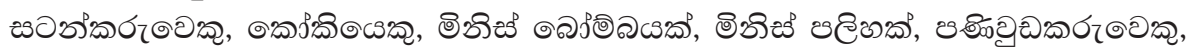

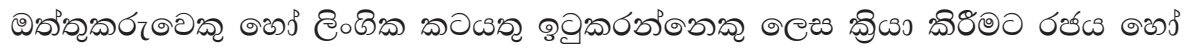

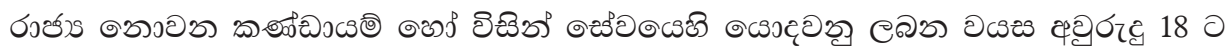

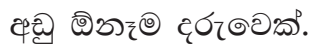

child soldier

Any child under the age of 18 recruited by the state or non-state groups to work as fighters, cooks, suicide bombers, human shields, messengers, spies, or for sexual purposes. (Azeez, 2019, p. 414)

There can be little doubt that we witness a scene of recruitment in both TDK and Yadam. This narrative, received within the context of the Sri Lankan conflicts of the early 1990s, connects to a set of public narratives denoted in the public imaginary through the

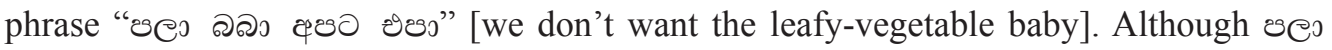
[pala] literally means leafy-vegetable in Sinhala, "pala baba apata epa" is a reference to protests organised to oppose the establishment of Provincial Councils under the 13th amendment to the Sri Lankan constitution in 1987. A protest campaign from 1987-1989 involved school children as well as adults. The school children who were not familiar 


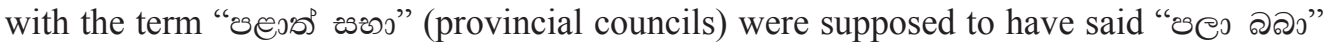
instead. ${ }^{13}$ This phrase took on a life of its own during the late 1980s and acted as a short hand to refer to the way in which innocents, such as school children, were used in political campaigns (Gunasekara, 2017).

An analysis of the final scene of the play is pertinent to the discussion of the public narrative concerning conflict and children. The Sinhala renarration, Yadam, departs from its $\mathrm{ST}$ in its ending. TDK ends on a note of jubilation with a freed Kimathi joining the masses in a "celebratory song". The stage directions read:

Utter commotion as a struggle between opposing forces ensues. A loud shot is heard.

Sudden darkness falls, but only for a moment: for soon, the stage gives way to a mighty crowd of workers and peasants at the centre of which are Boy and Girl, singing a thunderous freedom song. All the soldiers are gone, except for the First Soldier who shyly joins the singing from behind (wa Thiong'o \& Mugo, 1977, p. 84).

The sense of triumphant joy that clearly comes out in the scene described above, with the girl and boy at its centre, can be read as a continuity of Mau Mau politics through them. However, in Yadam, the ending had been altered significantly:

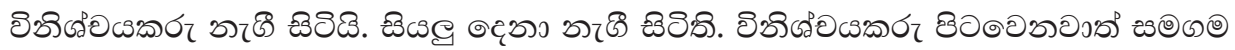

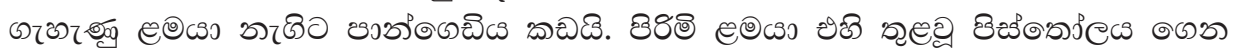

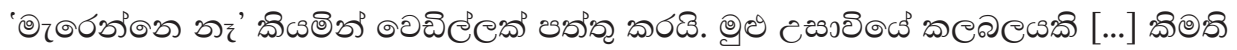

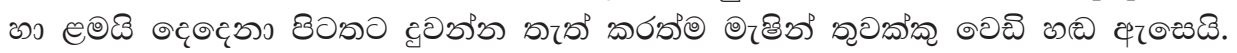

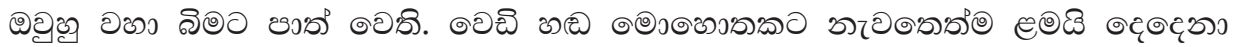

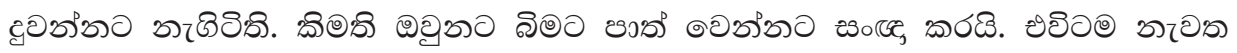

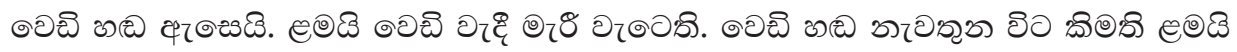

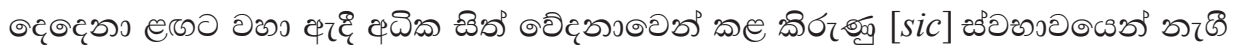

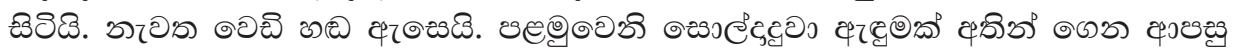

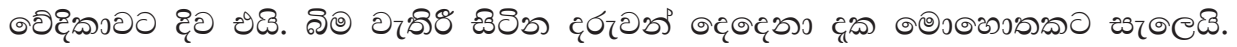





[my back translation:

The Judge rises. Everyone stands up. Just as the Judge leaves, the girl stands up and breaks open the loaf of bread in her hands. The boy grabs the gun that is hidden in it and fires a shot saying "will not die". There is commotion in court [...] When Kimathi and the two children attempt to leave, machine gun fire is heard. They crouch down. When the firing ceases momentarily, the two children attempt to flee. Kimathi signals them to crouch. The shooting starts again. The children fall, fatally shot. The moment the firing stops, Kimathi crawls over to the children and stands up looking deeply pained and sorrowful. Gunshots are heard again. The first soldier returns with some clothes in his hands. He sees the children motionless on the floor and stops for a moment as if in pain. He thrusts the clothes into Kimathi's hands and almost pushes him off stage. An African freedom song is heard in the background. The curtain closes slowly.] 
Yadam ends with the gunshots that kill the unnamed girl and boy who work to free Kimathi. Thus, although Kimathi escapes, there is no sense of triumph. The renarration has focussed on the lives of the girl and the boy to such an extent that there is strong audience identification with them and their narrative, leading to a feeling of shock and deep sorrow at the end. The devastatingly tragic ending of Yadam participates, therefore, in the public narrative on children and conflict on the children's behalf. This is a concern that is also wholly in keeping with Subasinghe's oeuvre, ${ }^{14}$ and her engagement with this particular public narrative can be seen, therefore, as a continuation of a strong theatrical preoccupation.

\section{Conclusion}

What is of significance to local-global interactions both via translation and narrative is the fact that narrative contributions such as Yadam's not only add to the circulation of public narratives within local contexts, but ultimately, through the process of narrative accrual, also contribute to their gaining global prominence as the narrative receives attention in different contexts (Sri Lanka being one such context). Identified by Bruner as the "cobbling together" of stories into a narrative whole, narrative accrual is "the outcome of repeated exposure to a set of related narratives, ultimately leading to the shaping of a culture, tradition or history" (Bruner, 1991, p.18; Baker, 2006). The history that is fashioned through this process could be personal or public, and may finally lead to the elaboration of meta narratives (Baker, 2006).

This insight regarding the connection between public and meta narratives brings me to my last point. Somers and Gibson define meta narratives as "narratives in which we are embedded as contemporary actors in history" (1994, p. 61). Somers calls them "the epic dramas of our time: Capitalism vs. Communism, the Individual vs. Society, Barbarism/ Nature vs. Civility" as well as "Progress", "Decadence" and "Enlightenment" (1992, p. $605)$. I would like to suggest that Justice too is such a meta narrative. Yadam's engagement with the two public narratives of justice and the judiciary, and children in armed conflict finally contributes to the meta narrative on Justice. The narrative concerning the judiciary is obviously connected to that on Justice. The one concerning children and armed conflict is also linked to the narrative on Justice as there is ultimately no justice for the two children because they are sacrificed for Kimathi's freedom. The reworked ending of the Sinhala renarration is key to how Yadam contributes to the meta narrative on Justice through its focus on children in conflict. Whilst this ending can be seen as a warning against the use of violence in rebellion, alluding to its detrimental impact on lives, Yadam can also be seen to address a nation that had lived through ten years of conflict by 1992 and tragedies such as the killing of school children in Embilipitiya during the reign of terror by those affiliated with the State (Mcgirk, 1994).

This article sought to discuss the manner in which texts produced in external geopolitical regions as well as within different temporalities can address local contexts through theatre translation as renarration. Using the analytical resources offered by socio narrative theory, the theatre translation Yadam was examined in relation to the concept of 
renarration. The discussion revealed that Yadam's intervention can be seen mainly in its engagement with two prominent public narratives. Public narratives gain in potency chiefly through the number of people participating in them. By adding its narrative voice to the ongoing debate on the role of the judiciary and justice in contexts of conflict, as well as that of children in combat, Yadam intervened in two highly significant public narratives to create awareness amongst Sri Lankan Sinhala audiences on the issues at stake. At the same time, it participated in the narration of global public narratives, and through narrative accrual, contributed to a meta narrative that is not just global in reach but exceeds temporal boundaries as well. At a point in time when those challenging government authority faced numerous forms of persecution, Subasinghe's renarration which placed theatre in the realm of political discourse can be read as a radical critique and intervention.

1. The two insurrections were by the Janatha Vimukthi Peramuna (JVP) in 1971 and 198889. "Eelam war" refers to the different phases of the armed conflict between the Sri Lankan state and the Liberation Tigers of Tamil Eelam (LTTE). These were secessionist wars aimed at creating a separate state for the Tamil people in the areas where they were the majority community. The period from July 1983 to May 2009 is divided into four phases (Eelam Wars I - IV).

2. Yadam, translated and directed by Somalatha Subasinghe, is analysed with the use of an unpublished manuscript of the translation, a recorded performance, publicity material from 5 different productions of the play from the 1990s and a number of published reviews of the play. These together constitute the 'primary narrative text'. I am extremely grateful to Anushaya Collure, Dr Chandana Aluthge and Kaushalya Fernando for giving me access to this material.

3. The concept of renarration was first introduced to Translation Studies (TS) by Mona Baker in her 2008 interview with Andrew Chesterman. In studies of literary translation, drawing on a combination of Poststructuralist narratology and socio narrative theory, Baldo (2009) examines the reconstruction of Italian-Canadian identities in Italian translations of migrant Italian-Canadian writing in English through the concept of re-narration. Summers (2012) examines the author-function in English translations of German writer Christa Wolf using a combination of Foucault's conception of author-function, socio narrative theory and the concept of (re) narration. The concept is mapped out in terms of its use within TS by Baker in a 2014 publication. The current study draws on the narrative framework presented in Karunanayake (2017) in relation to theatre translation and activism specifically.

4. A sample of ten such theatre translation titles: Вишнёвый сад (Russian ST), The Cherry Orchard (English TT), ๑е8 смэ (Sinhala TT); Der kaukasische Kreidekreis (German ST),





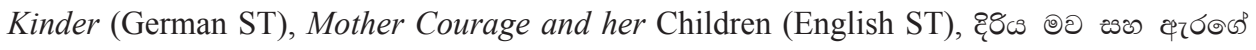

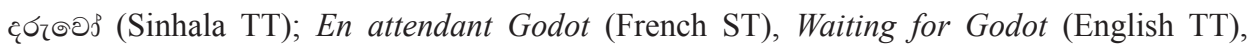

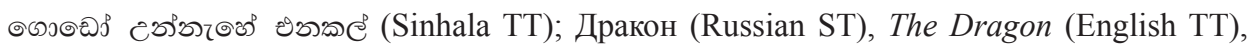

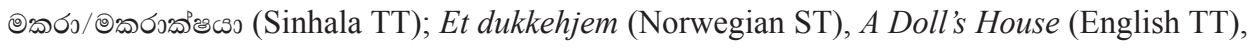

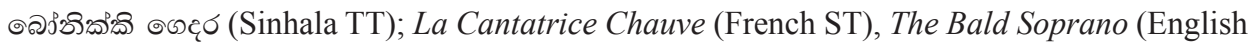




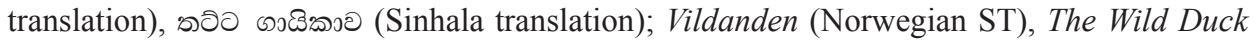

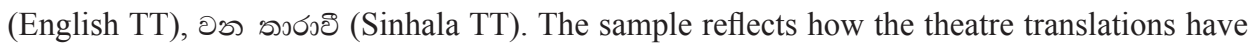
been given titles that reflect the ST title.

5. The following plays translated from English or other European languages into Sinhala have retained their titles. The names are merely transliterated: Hamlet, Othello, Julius Cesar, Antigone, Oedipus, Galileo and Marat - Sade.

6. Also known as "Indirect Translation", "Intermediate Translation", "Mediated Translation", or "Second-Hand Translation", the term is "used to denote the procedure whereby a text is not translated directly from an original ST, but via an intermediate translation in another language" (Shuttleworth \& Cowie, 2014, p. 76). The intermediary translation is usually in a language that is considered to be a lingua franca such as English (Proshina, 2005).

7. Defining translation as "rewriting" (Lefevere, 1992) or as quotation (Hermans, 2007, 2010) also implies that translating is a form of repeating, but with a difference, that a translation cannot be "the same as" a Source Text.

8. Hermans $(2007,2010)$, in theorising the concept of translation as quotation, also identifies the figure of the translator as active participant in the translation process. Lefevere's discussion of translation as rewriting similarly gives significance to the figure of the translator, particularly in relation to ideology. His discussion of Aristophanes' Lysistrata is particularly interesting in this regard (1992, p. 41-59). What differentiates the notion of renarration from these two is its use of many different elements in the narrative process, rather than the heavy text dependence to which both rewriting and quoting are prone. Lefevere also introduces the concept of refraction defined as "the adaptation of a work of literature to a different audience, with the intention of influencing the way in which that audience reads the work" (2000, p. 235).

9. Bruner (1991) uses the term 'narrative diachronicity' to refer to this feature.

10. 'Hermeneutic composability' in Bruner (1991).

11. The Sri Lankan judicial system is characterised by legal pluralism based on Roman-Dutch law, English Common Law and legislation, the Sri Lanka Constitution, and personal laws.

12. Since the 1950s, successive Sri Lankan governments have used the powers of the public security ordinance of 1947 to "silence critics and dissenters, and to inhibit the publication of information on such matters as human rights violations" (Nissan, 2001, p. 2330). The Prevention of Terrorism Act enacted as a temporary measure in 1979 and made a permanent law in 1982 together with Emergency Regulations were used to quell the 1988-1989 JVP movement and to engage in the Eelam wars. There was gross violation of due course of law during this period (Udagama, 1998).

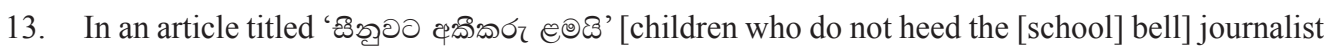
Denagama Siriwardena recounts an incident from 1989 at the Shariputta Maha Vidyala in Ahangama. A statement made by the Principal of the school, quoted in this article, sheds

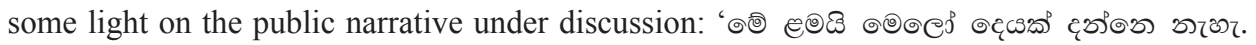

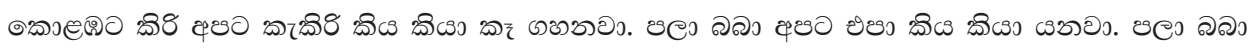

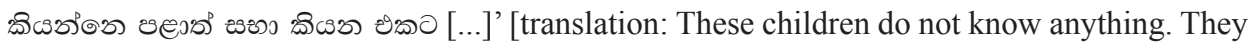
cry 'Colombo gets milk we get kekiri' (Kolambata kiri apata kekiri). They say, 'we don't want the leafy-vegetable baby' (pala baba apata epa). They call provincial councils leafy-vegetable 
baby (pala baba)']. Whilst it is unclear whether this article published in the Sinhala daily Dinamina in 2010 is based on a true account, what is important here is that the story details the public narrative surrounding the use of school children in conflict.

14. Subasinghe founded the Lanka Children's and Youth Theatre Foundation (LCYTF) (also known as Play House - Kotte) in 1981. The plays written specifically for children by her include Punchi Apata dan Therei [We Know It Now] in 1979, Thoppi Welenda [Hat Seller] in 1979, Gamarala Divya Loketa [The Farmer Going to Heaven] in 1981, Rathmalee [adaptation of Red Riding Hood] in 1981, Ottooi [Challenge] in 1988, Hima Kumariya [adaptation of Snow White and the Seven Dwarfs] in 1995 and Walas Pawula [adaptation of Goldilocks and Three Bears] in 2003. Her play Vikurthi [Distortion] first performed in 1982 focused on the problems of the education system of Sri Lanka, drawing attention to the burden placed on children through parental and societal expectations. She also directed an English version of the Trial of Dadan Kimathi for the British Council in Sri Lanka in 1992 and worked with children and young people both from her own theatre programmes as well as others for this production.

\section{References}

Azeez, A. H. (2019) 'Lama Soldaduva' [digital print]. In R. Cheran, Dinithi Karunanayake, Sharmini Pereira, Ruhanie Perera, T. Shanathanan and Geetha Sukumaran (Eds.) The A-Z of conflict (pg. 414). Raking Leaves.

Baker, M. (2006). Translation and conflict: A narrative account. Routledge.

Baker, M. (2014). Translation as re-narration. In J. House (Ed.), Translation: A multidisciplinary approach (pp. 158-177). Palgrave Macmillan.

Baker, M. \& Chesterman, A. (2008). Ethics of renarration - Mona Baker is interviewed by Andrew Chesterman, Cultus 1(1), 10-33. http://cw.routledge.com/textbooks/baker/data/articles/Baker_ Ethics_of_Renarration_2008.pdf

Baldo, M. (2009). Translation as Re-Narration in Italian-Canadian Writing - Codeswitching, Focalisation, Voice and Plot in Nino Ricci's Trilogy and its Italian Translation [unpublished PhD thesis]. University of Manchester, UK. https://www.researchgate.net/publication/324529652

Benjamin, W. (1996). The task of the translator. In M. Bullock \& M. W. Jennings (Eds.), Walter Benjamin: Selected writings. Vol. 1 1913-1926 (pp. 253-263). Belknap Press of Harvard UP.

Brown, N. (1999). Revolution and recidivism: The problem of Kenyan history in the plays of Ngugi waThiong'o. Research in African Literatures, 30(4), 56-73. https://www.jstor.org/stable/3820752

Bruner, J. (1991). The narrative construction of reality. Critical Inquiry 18(1), 1-21.

Coomaraswamy, R. \& de los Reyes, C. (2004). Rule by emergency: Sri Lanka's postcolonial constitutional experience. I.CON - International Journal of Constitutional Law, 2(2), 272-295. 10.1093/ICON/2.2.272

Dione, S. (2018). The politics of naming, misnaming and renaming in The Trial of Dedan Kimathi (1976) by Ngugi wa Thiong'o and Micere Githae Mugo. International Journal of Literature and Arts. 6(3), 44-53. 10.11648/j.ijla.20180603.11

Fonseka, B. (2001). The protection of child soldiers in international law. Asia-Pacific Journal on Human Rights and the Law, 2(2), 69-89. HeinOnline. file://C:/Users/USER/ Downloads/2AsiaPacJonHumRtsL69\%20(1).pdf 
Gunaratne, R. (1995). Sri Lanka a lost revolution? The inside story of the JVP. IFS.

Gunasekara, T. (2017). Remember? Remember! Ground Views - Journalism for Citizens. 08.15.2020 https://groundviews.org/2017/10/22/rememberremember/

Hermans, T. (2007). The conference of the tongues. St. Jerome.

Hermans, T. (2010). The translator as evaluator. In Mona Baker, Maeve Olohan and María Calzada (Eds.), Text and context: Essays on translation and interpreting in honour of Ian Mason (pp. 6376). St. Jerome.

Johnston, D. (1996). Theatre pragmatics. In David Johnston (Ed.), Stages of translation (pp 57-66). Absolute Press.

Johnston, D. (2013). Professing translation: The acts-in-between. Target 25 (3), 365-384. 10.1075/ target.25.3.04joh

Jürs-Munby, K. (2006). Introduction. In Lehmann, H. T. Postdramatic Theatre (K. Jürs-Munby, Trans.), (pp. 1-15). Routledge.

Karunanayake, D. (2017). Conflict and theatre translation: A narrative analysis of Saakki (1987). In K. Deslandes, F. Mourlon \& B. Tribout (Eds.), Civil War and Narrative (pp. 151-171). Palgrave Macmillan.

Lefevere, A. (1992). Translation, rewriting and the manipulation of literary fame. Routledge.

Lefevere, A. (2000). Mother Courage's Cucumbers: Text, system and refraction in a theory of literature. In L. Venuti (Ed.), The translation studies reader (pp. 233-249). Routledge. (Original work published 1982).

Lehmann, H. T. (2006). Postdramatic Theatre (K. Jürs-Munby, Trans.). Routledge. (Original work published 1999).

Lynch, M. (2019). Human rights prosecutions in democracies at war. Springer International Publishing.

Magel, E. A. (1983). Symbolism and regeneration in Ngugi wa Thiong'o's and Micere Mugo's The Trial of Dedan Kimathi. Canadian Journal of African Studies / Revue Canadienne des Études Africaines, 17(2), 239-245. https://www.jstor.org/stable/484216

Mcgirk, T. (1994, January 12). Report from the school of death. Independent. https://www.independent. co.uk/life-style/report-from-the-school-of-death-in-sri-lanka-a-gruesome-discovery-pits-full-ofthe-bodies-of-missing-1399498.html

Nissan, E. (2001). Sri Lanka. In Derek Jones (Ed.), Censorship: A world encyclopaedia (pp. 23302332). Routledge.

Obeyesekere, R. (1999). Sri Lankan theatre in a time of terror: Political satire in a permitted space. AltaMira Press.

Polkinghorne, D. E. (1995). Narrative configuration in qualitative analysis. In J. Amos Hatch and Richard Wisniewski (Eds.), Life history and narrative (pp. 5-23). The Flamer Press.

Proshina, Z. G. (2005). Intermediary translation from English as a lingua Franca. World Englishes 24, 517-522.

Shuttleworth, M. \& Cowie M. (2014). Dictionary of Translation Studies. Routledge.

Singer, P. P. (2004). Talk is cheap: Getting serious about preventing child soldiers. Cornell International Law Journal, 37(3), 561-586. https://scholarship.law.cornell.edu/cilj/vol32/iss3/20 
Siriwardena, D. (2010 September 06). Seenuwata akeekaru lamai. Dinamina - Sanwedi. http://archives.dinamina.lk/sanwedi/art.asp?id=2010/09/06/sPg03_0

Somers, M. R. (1992). Narrativity, narrative identity, and social action: Rethinking English working class formation. Social Science History, 16(4), 591-630.

Somers, M. R. (1994). The narrative constitution of identity: A relational and network approach. Theory and Society, 23, 605-649.

Somers, M. \& Gibson G.D. (1994). Reclaiming the epistemological 'other': Narrative and the social constitution of identity. In C. Calhoun (Ed.), Social theory and the politics of identity (pp. 37-99). Blackwell.

Subasinghe, S. (1992). Yadam [Unpublished manuscript].

Summers, C. S. (2012). Translating the author-function: The (re)narration of Christa Wolf. New Voices in Translation Studies, (8), 170 - 187. http://eprints.whiterose.ac.uk/id/eprint/76377

Udagama, D. (1998). Taming of the beast: judicial responses to state violence in Sri Lanka. Harvard Human Rights Journal, 11, 269-294. https://heinonline.org/HOL/Page?handle=hein.journals/ hhrj11\&collection=journals\&id=275\&startid $=$ \&endid $=300$

wa Thiong'o, N. and Mugo, M. G. (1977). The Trial of Dedan Kimathi. Heinemann.

White, H. (1987). The Content of the form: Narrative discourse and historical representation. John Hopkins University Press.

Wikramaratne, D. (2019). Satanini Satana. n.p. 